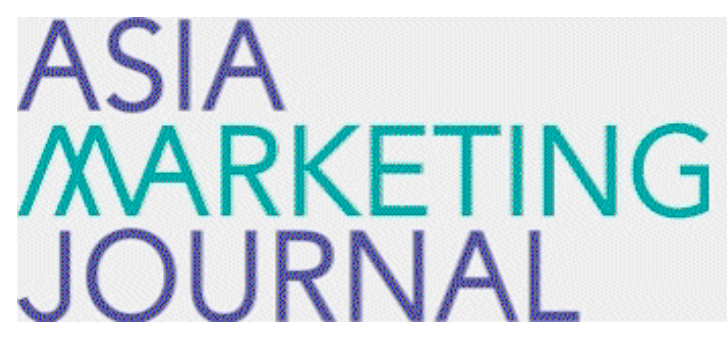

ASIA MARKETING JOURNAL

Volume 8 | Issue 3

Article 7

10-30-2006

\title{
음악 산업에 있어 성공적 비즈니스 모델인 SK Telecom의 멜론
}

\section{(MelOn)}

Pil Hwa Yoo

Suke Kyu Lee

Kyoung Sik Kim

Follow this and additional works at: https://amj.kma.re.kr/journal

Part of the Marketing Commons

\section{Recommended Citation}

Yoo, Pil Hwa; Lee, Suke Kyu; and Kim, Kyoung Sik (2006) "음악 산업에 있어 성공적 비즈니스 모델인 SK Telecom의 멜론(MelOn)," Asia Marketing Journal: Vol. 8 : Iss. 3 , Article 7.

Available at: https://doi.org/10.53728/2765-6500.1176

This Article is brought to you for free and open access by Asia Marketing Journal. It has been accepted for inclusion in Asia Marketing Journal by an authorized editor of Asia Marketing Journal. 


\title{
음악 산업에 있어 성공적 비즈니스 모델인 SK Telecom의 멜론(MelOn)
}

\author{
Successful Business Model on Music Industry: \\ SK Telecom MelOn
}

유 필 화(Yoo, Pil Hwa)*

이 석 규(Lee, Sukekyu)**

김 경 식(Kim, Kyoungsik)***

2004년 11월 16일 출시된 세계 최초의 유비쿼터스 음악 서비스인 SK Telecom의 멜론은 국내 음악 산업에서 새로운 비즈니스 모델로 성공을 거두었다. 멜론의 성공 배경에는 차별적인 서비스 특징 뿐 만 아니라 기술적 측면과 고객 지향적 측면에서 핵심 역량을 갖추고자 한 노력이 있다. 또한, 경쟁사 대비 비교 우위의 마케팅 믹스 활동도 간과할 수 없다. 본 사례에서는 멜론이 출시되기까지의 과정과 많은 사람들이 아직까지 생소해 하는 온라인 음악 서비스에 대해 소개하고, 성공을 향한 멜론의 노력 과 이를 통해 달성된 가시적 성과를 설명하였다. 그리고 지금보다 발전된 성과를 도출시키기 위해서 해결해야 할 전략적 과제를 제시하였다.

핵심개념: 멜론, 음악 산업, 성공적 비즈니스 모델, 유비쿼터스 음악 서비스

\section{I. 서 론}

음반 산업이란 음악 산업 중의 하나로 LP, $\mathrm{CD}$, 카세트테이프와 같은 음반의 제작, 배급 및 출판과 관련된 산업을 총칭한다. 그러나 최 근 들어 음반 산업은 ‘음반 제조업’ 뿐만 아니
라 ‘음악 서비스’를 포괄하면서 음악 산업과 동 일한 개념으로 사용되고 있다.

2000년 일반 가정에 초고속 인터넷 서비스가 확대되기 전까지 국내 음악 산업은 전통 음반 산업 구조가 중심이었다. 전통 음반 산업 구조 는 음반 기획사와 음반 제작사가 음반을 만들 면 도매상은 이를 대형 매장이나 소매상 등에

\footnotetext{
* 성균관대학교 GSB 교수(phyoo362@hitel.net)

** 성균관대학교 경영전문대학원 부교수(sukekyu@skku.edu)

*** 성균관대학교 경영연구소 연구원, 경영학박사(kdy620@skku.edu)
} 
판매하고 이 곳에서 음반을 구매한 소비자들은 $\mathrm{LP}, \mathrm{CD}$ 플레이어와 테이프 레코더로 음악을 듣는 구조를 말한다. 1995년 3,790억원이었던 전통 음반 산업 시장은 2000년에 4,104억원으로 최고점을 이루고 2004 년까지 매년 약 $25 \%$ 의 하락세를 보이고 있다. 이 같은 결과가 나타나 게 된 원인을 분석하면 다음과 같다. 먼저, 매 출 부진으로 인한 시장 규모의 축소이다. 특히, 음반의 불법 복제, 대형 가수와 히트곡 부재, 그리고 판매량이 보장되는 히트곡 위주의 편집 음반(compilation) 제작 남발이 매출 부진을 가 속화 시키고 있다. 또한, 시장 투명성 결여가 시장 규모를 축소시키는 역할을 하고 있다. 즉 연예 기획사와 언론 매체 간의 유착이 성행하 고 있는데, 실제로 가요 순위 프로그램이 음반 판매에 많은 영향을 미치기 때문에 음반 기획 사의 방송사 로비가 과열되고 기획사와 방송 제작진 간 보이지 않는 결탁과 뒷거래가 성행 하고 있다. 한편, 고비용, 저효율의 유통 시스템 도 심각한 문제로 지적받고 있다. 현재 음반 유 통의 흐름은 소수의 도매상 중심으로 이루어지 고 있다. 이러한 도매상은 인기 장르의 음반만 을 구매하려는 특징이 있다. 따라서 음반 제작 사는 인기 장르의 음반만을 만들 수 밖에 없는 데, 결과적으로 소비자들은 다양한 음반 선택 기회가 제한된다. 그러나 무엇보다 가장 큰 원 인은 앞서 언급한 초고속 인터넷 서비스의 확 대로 인한 $\mathrm{MP3}$ 파일 및 스트리밍 서비스 등 온라인 음악 서비스의 확산 때문이다. 또한, $\mathrm{MP3}$ 플레이어, MP3 휴대폰 등 재생 매체의 등장도 그 원인 중에 하나인데, 이 때문에 카세 트테이프, $\mathrm{CD}$ 등 기록 장치 산업은 구조 조정 또는 생산을 중단하는 악순환이 계속되고 있다
(고정민, 민동원 2003).

기존의 전통 음반 산업 시장이 축소되고 있는 것과는 다르게 온라인 음악 시장은 급격히 성 장하고 있다. 2000년 450억원이었던 시장 규모 가 연 평균 약 50\%씩 성장하면서 2004년에는 2,014 억원으로 1,338 억원이었던 전통 음반 산업 시장 규모를 넘어섰다. 특히, 2007년에는 시장 규모가 1.5 조원까지 늘어날 것으로 전망하고 있 다. 이러한 온라인 음악의 등장으로 기존의 전 통 음반 산업에서 볼 수 있었던 제작, 유통, 그 리고 소비자의 음반 수용 방식에 큰 변화가 일 어났다. 즉 전통 음반 산업 구조에서 탈피하게 되었는데, 음반 기획사는 음반 제작사가 아닌 음원 중계 에이전트와 음악을 만들어 $\mathrm{CP}$ (contents provider)에게 공급하면 소비자는 인 터넷 망과 무선 망을 이용하여 웹사이트에 접 근한 후, $\mathrm{MP3}$ 플레이어, $\mathrm{PC}$, 이동 전화, $\mathrm{PDA}$ 등을 통해 음악을 듣게 되는 것이다(김남훈 2005).

그러나 초기 온라인 음악 시장에는 치명적인 문제가 있었다. 즉 무료로 음악을 다운 받을 수 있는 온라인 사이트 그리고 다운을 받을 수는 없지만 무료로 음악을 들을 수 있는 음악 스트 리밍 사이트와 같은 불법 시장이 조성된 것이 다. 이러한 불법 시장의 규모는 합법 시장의 규모를 초과하고 있는데, 2001년 3,513억원이었 던 불법 시장의 규모는 2004년 7,270억원으로 2 배 이상 증가하였다. 1 차 디지털 충격(digital impact)이라고 불리는 이 기간 동안 발생된 불 법 시장의 확대는 음악 산업 전체를 침체시켰 다. 그러나 컬러링, 라이브벨 등의 데코레이션 시장 규모가 전통 음반 산업 시장 규모를 넘어 서면서, 침체된 음악 산업 시장의 신규 비즈니 
스 모델로 등장하기도 하였다. 비록 불법 음악 서비스 단속 강화로 2003년부터 불법 다운 로 드는 급감하고 있으나 2004년에 조사된 온라인 음악 서비스 사용 실태를 살펴보면, 유료 이용 자의 비율은 $4.1 \%$ 인데 반해 무료 이용자의 비 율은 $79.7 \%$ 에 이르고 있다. 이는 온라인 음악 서비스가 확산되었으나 유료 온라인 음악 서비 스는 아직 정착이 되지 않았음을 보여주는 것 이다.

그러나 이러한 상황에서 한 가지 중요한 사실 은 온라인 음악 서비스 이용자들이 점점 유료 온라인 서비스를 이용하기 시작 한다는 것이다. 이와 같은 유료화 시장 활성화와 저작권 보호 강화에 따라 2008년까지 온라인 음악 시장의 급속한 성장이 예상되는데, 이 때까지를 2 차 디 지털 충격의 시기로 볼 수 있다. 이 기간 동안, 불법 시장은 저작권 보호 활동에도 불구하고 음성적으로 일정 수준 유지될 것으로 보인다. 또한, 모바일 중심의 데코레이션 시장은 이동 통신 서비스 가입자의 증가 추세가 둔화되어 소규모 성장이 예상된다. 실제로 무료 음악 스 트리밍 사이트인 '벅스'의 일 방문자는 2003년 7월 270만명 이후 지속적으로 감소하고 있다. 이렇게 이용자들이 유료 온라인 서비스로 이동 하는 원인은 무료 음악 사이트와 음악계의 법 적 분쟁으로 인해 신곡 서비스 및 기존 서비스 가 제한되고 있기 때문이다. 이에 따라 많은 이 용자들은 점점 유료 온라인 음악 서비스의 이 용에 익숙해져 가고 있는데, 2003년에 비해 2004년 현재 유료 온라인 음악 서비스의 이용 의향이 약 $10 \%$ 증가한 것을 보면 알 수 있다. 실제로 2004년 1월부터 맥스 MP3(24만), 멜론 (8만), 쥬크온(9만), 뮤직온(3만) 등과 같은 유
료 음악 사이트의 이용이 꾸준히 동반 상승하 고 있다.

이에 본 연구에서는 짧은 기간 동안 많은 변 화가 있었던 국내 음악 산업에서 새로운 비즈 니스 모델로 성공을 거둔 SK Telecom의 멜론 사례를 살펴보고자 한다. 특히, 많은 사람들이 아직까지 생소해 하는 온라인 음악 서비스에 대해 멜론을 중심으로 설명하고, 온라인 음악 서비스로부터 파생된 마케팅 연구자와 실무자 들이 궁금해 하는 여러 가지 시장 환경의 변화 를 살펴보고자 한다. 동시에 급변하는 시장 환 경 속에서 보여준 멜론의 성공을 향한 노력과 이를 통해 달성된 가시적 성과를 언급하고자 한다.

\section{II. 멜론이란 무엇인가?}

\section{1 서비스 개요}

멜론은 멜로디 온(Melody On)의 줄임말로 SK Telecom에서 2004년 11월 16일 오픈한 $\mathrm{MP3}$ 곡 스트리밍/다운로드, 뮤직 비디오를 통 한 음악 감상과 컬러링, 라이브 벨 등의 폰꾸미 기 서비스를 갖춘 세계 최초의 유비쿼터스 음 악 서비스이다. 유비쿼터스(ubiquitous)는 도처 에 퍼져있다는 의미의 영어 형용사로 소비자가 서비스 사용을 위해 노력하기 보다는 서비스가 항상 소비자 주변에 존재하여 원하는 방식으로 찾아간다는 의미를 갖는 서비스이다. 또한, 멜 론의 의미는 인간의 삶에 있어 신선한 활력과 상큼한 즐거움을 선사하고자 하는 서비스 정신 
을 의미한다. 정리하면, 유비쿼터스 서비스 멜 론은 언제 어디서나 음악을 즐길 수 있도록 멜 론 웹사이트, 멜론 플레이어 뿐 아니라 JUNE 이나 NATE와 같은 무선 환경에서도 멜론에 접속할 수 있는 환경을 제공하고 있다. 따라서 소비자들은 멜론의 모든 음악에 대한 실시간 음악 감상(스트리밍) 및 다운로드가 가능하며, $\mathrm{PC}$, 휴대폰, $\mathrm{MP} 3$ 플레이어 등 원하는 디바이 스 어디에든 저장해서 감상 할 수 있다. 이에 대해 구체적으로 설명하면, 먼저, 멜론 상품은 크게 2 가지로 구분된다. 매월 자동 결제로 이루 어지는 정액제 상품으로 정액제 해지 전까지 모든 음악을 자유롭게 이용할 수 있는 클럽 상
품이 있고, 구입한 티켓 기간 동안 멜론의 모든 음악을 자유롭게 이용할 수 있는 선납 상품인 티켓 상품이 있다. 이에 대한 자세한 내용은 <표 1>에 정리되어 있다. 또한, 멜론 서비스를 이용 가능하게 하는 디바이스에는 실시간 음악 감상 및 다운 로드 서비스를 가능하게 하는 $\mathrm{PC}$ 가 있다. 그리고 휴대폰이 있는데, SK Telecom $\mathrm{MP3}$ 폰과 멜론 모바일 가능 폰이 그것이다. 전자에는 유선 다운 로드( $\mathrm{PC}$ 다운 로드 후 폰 전송) 기능이 있다. 2006년 2월 현재 약 300만 명이 사용 중이며, 연말까지 약 600 만명이 사용 할 것으로 예상하고 있다. 한편, 후자에는 무선 다운 로드(JUNE/NATE 멜론 메뉴 접속) 기

\section{<표 1> 멜론 상품}

<클럽 상품>

\begin{tabular}{|c|c|c|c|c|c|}
\hline 구분 & $\begin{array}{c}\text { 이용 } \\
\text { 서비스 }\end{array}$ & $\begin{array}{c}\text { 가격 } \\
\text { (월 정액제) }\end{array}$ & $\begin{array}{l}\text { 이용 } \\
\text { 곡 수 }\end{array}$ & $\begin{array}{l}\text { 곡 이용 } \\
\text { 기간 }\end{array}$ & $\begin{array}{l}\text { 과금 } \\
\text { 방법 }\end{array}$ \\
\hline 프리클럽 & $\begin{array}{l}\text { 실시간 음악 감상 } \\
\text { 프리 다운 로드 } \\
\text { 뮤직 비디오 감상 }\end{array}$ & $\begin{array}{c}\text { 월 } 4,500 \text { 원 } \\
\text { (첫째달 } 5,000 \text { 원) }\end{array}$ & \multirow[t]{2}{*}{ 무제한 } & \multirow{2}{*}{$\begin{array}{c}\text { 정액제 해지 } \\
\text { 시까지 } \\
\text { (시작일로 } \\
\text { 부터 한달 단위) }\end{array}$} & \multirow{2}{*}{$\begin{array}{l}\text { SKT } \\
\text { 청구서 } \\
\text { 또는 신용 } \\
\text { 카드 결제 }\end{array}$} \\
\hline 스트리밍클럽 & $\begin{array}{l}\text { 실시간 음악 감상 } \\
\text { 뮤직 비디오 감상 }\end{array}$ & 월 3,000원 & & & \\
\hline
\end{tabular}

<티켓상품>

\begin{tabular}{|c|c|c|c|c|c|}
\hline 구분 & $\begin{array}{c}\text { 이용 } \\
\text { 서비스 }\end{array}$ & 가격 & $\begin{array}{c}\text { 이용 } \\
\text { 곡 수 }\end{array}$ & $\begin{array}{c}\text { 곡 이용 } \\
\text { 기간 }\end{array}$ & $\begin{array}{c}\text { 과금 } \\
\text { 방법 }\end{array}$ \\
\hline 프리티켓 & $\begin{array}{c}\text { 실시간 음악 감상 } \\
\text { 프리 다운 로드 }\end{array}$ & $\begin{array}{c}\text { 월 } 5,000 \text { 원(1개월권) } \\
(1,3,6,12 \text { 월 이용권) }\end{array}$ & 무제한 & $\begin{array}{c}\text { 티켓 기간 종료 } \\
\text { 시 까지 }\end{array}$ & $\begin{array}{c}\text { SKT } \\
\text { 청구서 및 } \\
\text { 멜론 캐쉬 }\end{array}$ \\
\cline { 1 - 3 } 스트리밍티켓 & 실시간 음악 감상 & 월 3,000 원(1개월권 $)$ & & &
\end{tabular}

<프리티켓 이용 가격>

\begin{tabular}{|c|c|c|c|c|}
\hline 이용 기간 & 1개월 & 3개월 & 6개월 & 12 개월 \\
\hline $\begin{array}{c}\text { 가격 } \\
\text { (할인율) }\end{array}$ & $\begin{array}{c}5,000 \text { 원 } \\
(0 \%)\end{array}$ & $\begin{array}{l}\text { 14,500원 } \\
(-3.3 \%)\end{array}$ & $\begin{array}{l}28,000 \text { 원 } \\
(-6.7 \%)\end{array}$ & $\begin{array}{l}55,000 \text { 원 } \\
(-8.3 \%)\end{array}$ \\
\hline 프리클럽과 비교 & 5,000 원 & 14,000 원 & 27,500 원 & 54,500 원 \\
\hline
\end{tabular}


능이 있다. 이 또한 약 400 만명이 사용 중이다. 마지막으로 음악을 다운 로드하여 들을 수 있 는 MP3 플레이어가 있는데, 레인콤의 아이리 버(iRiver), 코원의 아이오디오(iAudio), 삼성의 옙(Yepp), 그리고 아이옵스(IOPS) 등 대부분 의 기종에서 서비스를 지원하고 있다.

\section{2 서비스 특징}

멜론의 주요 고객은 멜론 서비스가 가능한 $\mathrm{MP3}$ 휴대폰 및 $\mathrm{MP3}$ 플레이어 소유자 모두 이다. 그 중 인터넷 활용도가 높은 10 대 30 대를 주요 목표 고객으로 하고 있다. 이러한 고 객을 대상으로 한 멜론은 국내 최대의 합법적 인 음원을 보유하고 있다. 따라서 멜론 사이트 내에서의 모든 활동은 저작권 및 모든 제약 조 건에서 자유롭다. 그리고 멜론에서 한번 구매한 음악은 일정 기간 추가 요금 없이 $\mathrm{PC}$, 휴대폰, $\mathrm{MP} 3$ 플레이어 등 어떤 기기에서든지 들을 수 있다. 단, 음원의 저작권 보호를 위한 DRM (digital rights management) 방식을 적용하여 휴대폰 1대, MP3 플레이어 1대에서만 이용 가 능하다. 그러나 실시간 음악 감상은 어느 $\mathrm{PC}$ 에 서나 가능하다. 또한, 전 세계 최신 인기 음악 을 멜론에서 가장 먼저 들을 수 있는데 멜론에 서 제공하는 쇼케이스(showcase)에서는 그러한 음악을 앨범이 발매되기 전에 디지털 음악과 뮤직 비디오를 통해 최초로 공개한다. 한편, 멜 론에서는 음악 다운 로드 서비스 뿐만 아니라, 가입한 기간 또는 구입한 티켓 기간 동안 모든 음악을 무제한으로 실시간 감상할 수 있다. 동 시에 추가 정보 이용료 없이 프리 다운 로드 할 수 있는 음악 렌털 서비스를 제공받을 수
있다. 이를 통해 알 수 있듯이 멜론은 다른 음 악 포털 서비스와 비교 했을 때, 그 서비스 특 징 면에서 확실한 비교 우위를 점하고 있다. 그 결과, 2006년 2월 현재 멜론의 홈페이지에 가입 한 회원은 무료 회원을 포함해서 모두 450만명 에 이르고 있는데, 이 중 정액제 유료 고객이 약 65 만명이다. 또한, 홈페이지 하루 방문자 수 도 약 40 만명에 육박하고 있다.

\section{3 경쟁사 유사 서비스와의 비교}

SK Telecom의 멜론과 경쟁하고 있는 경쟁사 유사 서비스는 크게 2 부류로 나누어 볼 수 있 는데, 소리바다, 벅스와 같이 기존의 음악 포털 사이트에서 제공하는 서비스와 $\mathrm{KTF}, \mathrm{LG}$ Telecom과 같은 경쟁 이동 통신 서비스 업체에 서 제공하는 서비스가 그것이다. 그러나 멜론과 비교하여 소리바다에서 제공하는 서비스는 합 법적으로 권리가 확보된 서비스가 아니다. 그리 고 벅스에서 제공하는 서비스는 $\mathrm{MP} 3$ 휴대폰으 로 음악 파일을 전송할 수 없어 그 범용성 측 면에서 현저히 떨어진다(<표 2> 참고). 이와 함 께 SK Telecom의 멜론과 비교하여 KTF에서 오픈한 도시락(dosirak)은 2006년 2월 현재 정 액제 유료 고객이 약 30 만명이고 홈페이지 하 루 방문자 수도 약 6 만명으로 많은 수준 차이 를 보이고 있다. 한편, LG Telecom에서 2004년 12 월 오픈한 뮤직온(musicON) 서비스는 현재 방문자 수 기준으로 업계 10 위 수준으로 매우 열위에 있다. 정리하면, 유무선 통합 포털 서 비스를 구축한 멜론이 서비스 접근성 측면에서 다른 경쟁사 유사 서비스와 비교하여 최고의 경쟁력을 확보하고 있다. 
<표 2> 멜론과 경쟁사 유사 서비스와의 고객 접점 경쟁력 비교(2005년 5월 기준)

\begin{tabular}{|c|c|c|c|c|}
\hline & $\begin{array}{c}\text { 유선 스트리밍 / } \\
\text { 다운로드 }\end{array}$ & $\mathrm{MP3}$ 플레이어 & $\mathrm{MP3}$ 휴대폰 & 무선 인터넷 \\
\hline 멜론 & $\mathrm{O}$ & $\mathrm{O}$ & $\mathrm{O}$ & $\mathrm{O}$ \\
\hline 벅스 & $\mathrm{O}$ & $\mathrm{O}$ & $\mathrm{X}$ & $\mathrm{X}$ \\
\hline 도시락 & $\mathrm{O}$ & $\mathrm{O}$ & $\mathrm{O}$ & $\mathrm{O}$ \\
\hline 뮤직온 & $\mathrm{O}$ & $\mathrm{X}$ & $\mathrm{O}$ & $\mathrm{X}$ \\
\hline
\end{tabular}

최근에 작성된 소비자 조사 보고서에 따르면, 소리바다, 벅스, 도시락과 비교하여 멜론은 최 초 상기 측면에서 $45.6 \%$ 로 가장 높은 인지 수 준을 보이고 있다(<표 $3>$ 참고). 이는 장기간 음악 사이트를 이용해 온 이용자들에게 있어 멜론의 최근 광고가 인지 수준을 높이는데 소 구력을 발휘하였음을 보여주는 것이다. 또한, 최근 3 개월간 이용 경험과 현재 주 이용 실태 에 관한 조사에서 멜론이 가장 높은 순위를 보 이고 있는데(<표 $4>$ 참고), 이는 최근 1 년 사이 에 온라인 음악 서비스의 유료화 및 음원 사용 과 관련하여 문제가 있었던 소리바다와 벅스의 기존 이용자가 많이 이탈한 것에 기인한다. 한 편, 멜론은 전체적인 사이트의 신뢰도 측면에서 가장 높은 점수를 획득했는데, 이와 함께 권유
가능성, 자신과의 적합성, 친근감 등 사이트 이 미지 측정 항목에서도 비교 우위를 점하고 있 다(<그림 $1>$ 참고). 온라인 음악 서비스 이용자 들이 가장 중요하게 고려하는 혜택 이미지 요 인은 음질이다. 그리고 시스템 안정성, 업데이 트 신속성, 속도 안정성 순이다. 그런데 이러한 전반적인 요인과의 관계성 측면에 있어서 멜론 은 매우 유의미한 결과를 도출시키고 있다. 구 체적으로 설명하면, 멜론은 경쟁사와 비교했을 때, 음원이 많다는 점과 시스템이 안정적이라는 강점을 가지고 있다(<그림 $2>$ 참고). 결론적으 로 멜론은 경쟁사 유사 서비스와 비교하여 강 력한 경쟁력을 소유하고 있고, 이에 대해 대부 분의 이용자들도 온라인 음악 서비스 시장 내 높은 위상을 인정하고 있다.

<표 3> 멜론과 경쟁사 유사 서비스와의 최초 상기도 비교 $(\mathrm{N}=540, \%)$

\begin{tabular}{|c|c|c|c|c|}
\hline 멜론 & 도시락 & 소리바다 & 벅스 & 기타 \\
\hline 45.6 & 19.6 & 17.6 & 15.5 & 1.7 \\
\hline
\end{tabular}

<표 $4>$ 멜론과 경쟁사 유사 서비스와의 이용 경험 비교 $(\mathrm{N}=540, \%)$

\begin{tabular}{|c|c|c|c|c|}
\hline & 멜론 & 도시락 & 소리바다 & 벅스 \\
\hline 최근 3개월간 & 56.8 & 28.2 & 28.7 & 41.7 \\
\hline 현재 & 48.8 & 24.8 & 8.0 & 13.7 \\
\hline
\end{tabular}

* 중복 응답 허용 
<그림 $1>$ 멜론과 경쟁사 유사 서비스와의 사이트 이미지 비교

$(\mathbb{N}=540, \%)$

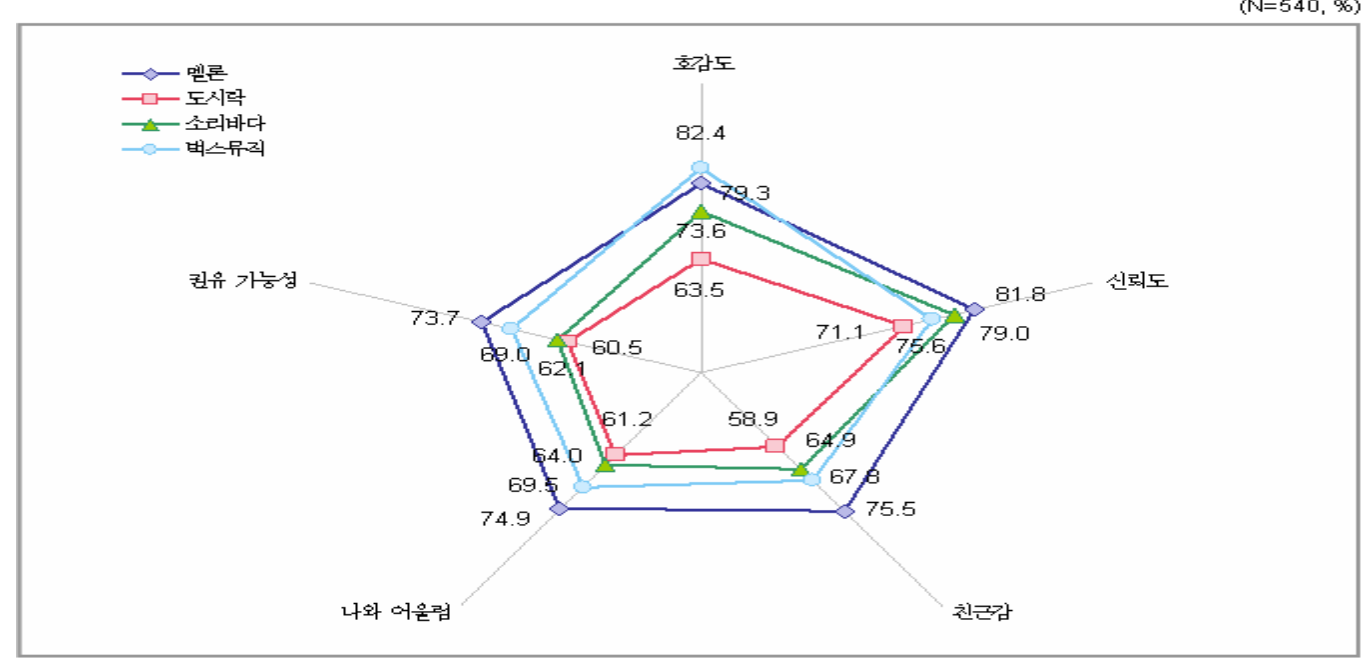

<그림 $2>$ 멜론과 경쟁사 유사 서비스와의 혜택 이미지 비교

\section{- Positioning Map(corr) -}

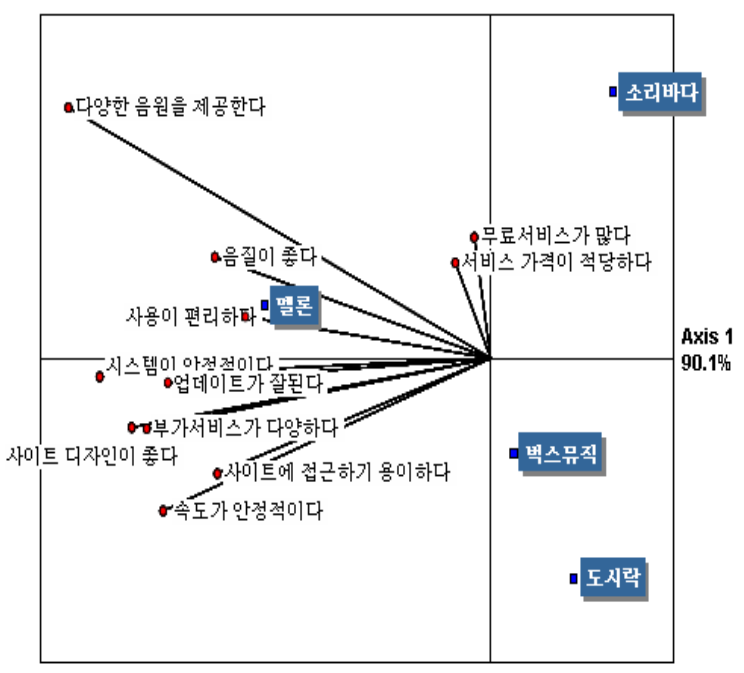

Axis $27.3 \%$
- Positioning Map(Bi Plot) -

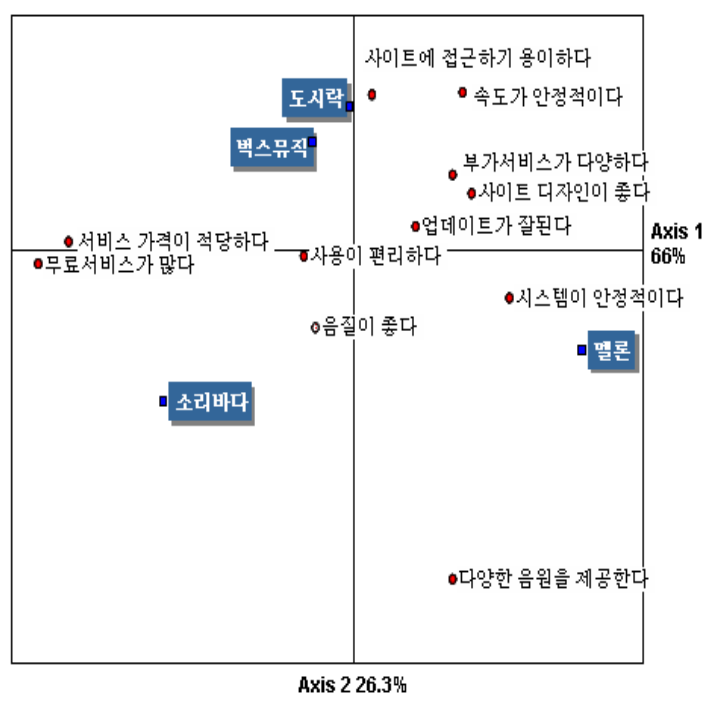




\section{III. 성공을 향한 노력}

Gatignon and Xuereb(1997)의 연구를 살펴 보면, 새롭게 시장에 출신된 혁신 제품의 성과 측정은 그 제품이 속한 산업군의 특징과 그 제 품이 행한 마케팅 전술 측면에서의 혁신성에 기준을 두고 이루어진다. 특히, 높은 성과를 보 이는 혁신 제품은 다음 3 가지에 핵심 역량을 나타내는데, 첫째, 기술 지향적(technological orientation)이다. 기술 지향적 제품은 R\&D에 집중하고 새로운 기술을 받아들이려는 준비가 항상 되어있어, 변화가 심한 기술적 환경에 새 로운 지식을 접목하여 빠르게 적응한다. 둘째, 고객 지향적(customer orientation)이다. 고객 지향적 제품은 목표 고객들에게 새로운 가치를 지속적으로 제공하기 위해 항상 그들을 이해하 려고 노력한다. 특히, 고객이 흥미롭게 생각하 는 것을 최우선하여, 그것을 정의하고, 분석한다. 셋째, 경쟁자 지향적(competitor orientation)이 다. 경쟁자 지향적 제품은 본질적으로 경쟁에서 승리하기 위해, 경쟁자의 움직임을 항상 분석하 고 이에 따라 반응한다. 이를 통해 제품을 바르 게 포지셔닝 할 수 있게 된다.

혁신 제품의 하나로써 멜론을 살펴보면, 온라 인 음악 산업군에 있어 기술 지향적인 특징이 두드러진다. 또한, 마케팅 전술 측면에서 있어 고객 지향적인 방향으로 항상 움직이려 한다. 그러나 온라인 음악 시장에 처음으로 진입한 제품으로써 경쟁의 범위가 매우 좁아 경쟁자의 움직임을 벤치 마킹하기는 쉅지 않다. 이를 통 해, 본 장에서는 성과가 높은 혁신 제품이 일반 적으로 소유하고 있는 핵심 역량을 토대로 멜
론이 행한 노력을 제시하고자 한다. 특히, 기술 지향적인 측면과 고객 지향적인 측면에 초점을 맞추고자 한다.

\section{1 기술 지향적 관점에서의 노력}

엄밀히 말하면, 소비자가 음악을 듣게 되는 기술적 메카니즘을 설명하는 것은 본 사례의 범위를 벗어나는 것이다. 그러나 온라인 음악 시장의 기술적 구조를 설명하는 것은 마케팅 전략 수립에 있어 거시 환경을 분석하는데 도 움이 될 것으로 사료된다.

일반적으로 온라인 음악 시장은 음원의 공급 처를 확보하는 활동인 소싱(sourcing) 및 확보 된 공급처를 통하여 음원을 공급하는 활동인 $\mathrm{POC}$ (point of contact)와 공급된 음원을 소비 자들이 들을 수 있게 하는 터미널(terminal)로 구성된다. 이 때, 각각의 구성 요소가 원활히 융합되어 활동할 수 있도록 하는 DRM은 온라 인 음악 시장에서 핵심 요소로 제기되고 있다 (<표 $5>$ 참고). 참고로 $\mathrm{DRM}$ 이란, 인터넷을 통 한 유료 콘텐츠의 불법 복제를 방지하기 위해 개발된 저작권 관리 소프트웨어를 의미한다.

이러한 상황 하에서, 멜론은 휴대폰 데코레이 션 시장의 성장이 둔화될 것을 예상하고 무선 중심의 비즈니스 모델이 차세대 성장 동력으로 부상할 것을 예상하게 된다. 이를 통해, 유무 선 음악 감상 시장으로의 사업 영역 확대 등의 적극적인 사업 기회를 발굴하려 한다. 또한, 유 료 온라인 음악 시장에서의 최강의 음원 보유 력을 통해 음원 소싱에서부터 터미널까지 온라 인 음악 시장의 기술적 구조 전반에 걸쳐 새로 운 사업 기회를 확보하려 한다. 특히, $\mathrm{POC}$ 의 
<표 5> 온라인 음악 시장의 기술적 구조

\begin{tabular}{|c|c|}
\hline & Sourcing \\
\hline 정의 & $\begin{array}{c}\text { 기획사 및 } \\
\text { 음반사로부터 } \\
\text { 컨텐츠를 } \\
\text { 확보하는 접점 }\end{array}$ \\
\hline \multirow{3}{*}{ 공급원 } & $\begin{array}{c}\text { 대형 음반사 } \\
\text { 대형 기획사 } \\
\text { 에이전시 }\end{array}$ \\
\hline 비고 & $\begin{array}{c}\text { 온라인 환경- } \\
\text { 컨텐츠 활용, } \\
\text { 음원 확보 } \\
\text { 역량 중요 }\end{array}$ \\
\hline
\end{tabular}

경쟁력을 강화하려 노력하는데, 유선뿐만 아니 라 무선 그리고 심지어 방송 영역으로 $\mathrm{POC}$ 를 확장하고 기존의 $\mathrm{POC}$ 를 통합하여 이를 추진하 려 한다. 또한, 터미널의 영역을 확장하려 하는 데, 기존의 $\mathrm{PC}$ 및 $\mathrm{MP} 3$ 플레이어뿐만 아니라 새롭게 개발되고 있는 휴대용(portable) 미디어 플레이어에 대한 사업 영역을 확장하려 한다.

\section{1 .1 소싱 영역에서의 경쟁력 확보}

온라인 음악 시장에서 경쟁력을 갖기 위해서 는 많은 음원을 확보하는 것이 중요하다. 그러 나 더욱 중요한 것은 음원과 관련된 법적 권리 에 대한 해법을 마련하는 것이다. 여기서 말하 는 법적 권리는 다음과 같이 크게 3 가지로 분 류할 수 있다. 첫째, 복제권/공연권/배포권/방 송권/전송권에 관한 저작자의 권리. 둘째, 복제 권/방송권/방송 사용에 대한 보상 청구권에 관 한 실연자의 권리. 셋째, 복제권/배포권/방송 사용에 대한 보상 청구권에 관한 음반 제작자

\begin{tabular}{|c|c|c|}
\hline $\mathrm{POC}$ & \multirow{4}{*}{$\begin{array}{c}\text { 불법 유통 } \\
\text { 차단을 위한 } \\
\text { DRM }\end{array}$} & Terminal \\
\hline $\begin{array}{c}\text { 고객에게 } \\
\text { 컨텐츠를 } \\
\text { 배달하는 핵심 } \\
\text { 비즈니스 영역 }\end{array}$ & & $\begin{array}{c}\text { 고객의 컨텐츠 } \\
\text { 사용 환경에 } \\
\text { 따라 존재하는 } \\
\text { 다양한 디바이스 }\end{array}$ \\
\hline $\begin{array}{c}\text { 유선POC } \\
\text { 무선POC } \\
\text { 공중파/CATV } \\
\text { 위성DMB }\end{array}$ & & $\begin{array}{c}\mathrm{PC} \\
\mathrm{MP3} \text { 플레이어 } \\
\text { MP3 휴대폰 }\end{array}$ \\
\hline $\begin{array}{c}\text { 컨텐츠의 급속한 } \\
\text { 디지털화로 } \\
\text { 다양한 형태의 } \\
\text { POC 탄생 }\end{array}$ & & $\begin{array}{c}\text { 터미널의 보급 } \\
\text { 정도가 고객 } \\
\text { 지향적 } \mathrm{POC} \text { 의 } \\
\text { 정도를 의미 }\end{array}$ \\
\hline
\end{tabular}

의 권리이다. 여기서 현재 논란이 되고 있는 것 이 바로 전송권 부분이다. 즉 음원을 서버에 고 정시키는 행위인 복제 행위는 불법이지만 전송 행위인 스트리밍 서비스까지 불법으로 볼 수 있느냐이다. 이에 대해 음반 제작자 입장에서는 전송권을 법적 권리로 포함시킬 것을 요구하고 있고, 음악 사이트 입장에서는 복제권과 전송권 을 엄격히 분리 적용할 것을 요구하고 있다. 이 러한 상황 하에서 발효된 개정 저작인접권법은 기존 저작권자에게 제한되어 있던 전송권을 저 작인접권자에게도 부여하였는데, 이를 통해 가 수와 연주자 같은 실연자 및 음반 제작자 등도 통신망을 이용한 불법적인 음원 파일의 유통에 대하여 법적인 조치를 취할 수 있게 되었다.

이러한 측면에서 현재 약 100 만곡 상당의 음 원을 확보하고 있는 멜론은 국내 최대의 마켓 플레이스를 기반으로 하여 소싱 영역에서 경쟁 력을 확보하고 있다. 이는 음원권자와의 원활한 제휴를 통해 컨텐츠 수급의 안정성을 확보한 것에 기인한다. 음원권자와의 원활한 제휴는 음 
원 권리의 $\mathrm{DB}$ 화와 투명한 정산이 가능한 $\mathrm{MLB}$ (music license bank)를 구축함으로써 가 능했다. 또한, MLB는 멜론의 무선 $\mathrm{POC}$ 경쟁 력을 활용한 합법적 음원 수급의 게이트웨이 역할을 하였는데, 결과적으로 $\mathrm{MLB}$ 구축은 음 원권자와 $\mathrm{POC}$ 사업자간 윈-윈을 발생시켜 불 법 시장을 조기에 양성화하여 음원 권리자의 혜택을 극대화시켜 주었다.

한편, 컨텐츠 수급의 안정성은 컨텐츠 유통 사업 진출 및 제휴를 통해서도 확보했다. 우선 2005년 6월 업계 1위의 음반사인 YBM 서울 음반을 인수해 음원을 안정적으로 확보했다. 이 러한 YBM 서울 음반 인수는 디지털 유통망을 확보하고 신규 디지털 시장을 창출하는데 시너 지 효과를 내주었다. 한편, 약 400억원의 투자 펀드를 조성해 기획사 및 음반사와의 전략적 제휴 그리고 해외 진출 프로젝트 등에도 투자 하였다. 이를 통해 SK Telecom이 음악 시장의 투자 제작과 배급을 겸하는 종합 음악 회사로 발전할 수 있는 기틀이 마련되었다.

\subsection{2 $\mathrm{POC}$ 영역에서의 경쟁력 확보}

음원권을 최대한 보호한 상태에서 많은 음원 을 확보하는 것도 중요하지만 그 만큼 음원을 공급하는 것도 중요하다. 현재 컨텐츠가 급속하 게 디지털화 되고 있는 상황에서 다양한 $\mathrm{POC}$ 가 탄생하고 있다. 이러한 측면에서 유무선 플렛폼에 관한 운영 Know-how를 충분히 축적 한 멜론은 $\mathrm{POC}$ 영역에서 강력한 경쟁력을 확 보하고 있다. SK Telecom과 Intel 간의 디지털 홈 엔터테인먼트 분야 양해 각서(MOU) 체결 로 이제 멜론을 $\mathrm{TV}$ 로도 즐길 수 있게 되었다.
이렇게 체결된 양해 각서는 프리미엄 디지털 홈 컨텐츠에 관한 것으로 멜론과 기술적으로 관련된 부분을 한층 강화할 수 있는 새로운 기 회가 형성되었다. 즉 하드웨어 및 소프트웨어의 가능화(enablement) 작업을 통해 홈 네트워크 로 접속된 $\mathrm{TV}$ 의 리모콘을 몇 번 누름으로써 멜론에서 제공되는 음악과 뮤직비디오를 다운 받아 즐길 수 있게 되었다. 동시에 다운 로드 받은 컨텐츠를 노트북이나 MP3 플레이어에 담 아 이동 중에도 즐길 수 있는 편안함과 여유로 움을 얻게 되었다.

이와 같이 디지털 홈 시장에 진출할 수 있는 교두보 확보는 멜론이 유무선 통합 포털 구 축으로 음원 공급 측면에서 최고의 경쟁력을 소유했기에 가능했다. 이를 통해 멜론은 음원 유통 채널을 위성 $\mathrm{DMB}$ 영역에 까지 확장할 수 있었다. 유통 채널에 대한 경쟁력 확보는 자 연스럽게 서비스에 대한 영역 확장을 가능하게 했다. 따라서 다운로드와 스트리밍 서비스에 일 관하던 서비스가 음악 정보, 음악 방송, 음악 커뮤니티, $\mathrm{P} 2 \mathrm{P}$ 커뮤니케이션 등으로 급속히 확 장되었다. 그리고 심지어 인공 지능 서비스인 멜론 에이전트의 탄생도 가시권에 들어오게 되 었다. 한편, 소싱 영역과 마찬가지로 소비자에 게 음원을 공급하는 $\mathrm{POC}$ 영역에서도 $\mathrm{DRM}$ 은 불법 유통 차단에 있어 중요한 역할을 하였는 데, 멜론은 이 부분에 대해서도 차별적 경쟁력 을 추가 확보하였다.

\subsection{3 터미널 영역에서의 경쟁력 확보}

지금은 소비자의 컨텐츠 사용 환경에 따라 다 양한 디바이스가 개발되는 추세이다. 온라인 음 
악 시장에서 공급된 음원을 소비자들이 들을 수 있게 하는 디바이스를 총칭하여 터미널이라 하는데, 현재는 터미널의 영역이 확장되어 기존 의 $\mathrm{PC}$ 및 $\mathrm{MP} 3$ 플레이어뿐만 아니라 휴대용 미디어 플레이어가 새롭게 개발되고 있다. 이 중 휴대폰에 대한 관심이 높아지고 있는데, 마 이크로소프트 회장 빌 게이츠는 2005년 독일의 유력지인 알게마이네 자이퉁과의 인터뷰에서 "아이포드(i-Pod) 등 MP3 플레이어가 우위를 점하고 있는 온라인 음악 시장을 휴대폰이 점 령하게 될 것이다.”라고 언급했다. 솔직히 단순 히 음악 파일만을 재생하는 독립적인 형태의 $\mathrm{MP3}$ 플레이어가 아예 사라지지는 않을 것이 다. 그러나 음악 재생 기능을 아우르는 휴대폰 이 대표적인 휴대용 멀티 미디어 기기로 소비 자들의 선택을 받을 것이 확실하고 현재 그렇 게 되고 있다. 따라서 그래픽 사용자 인터페이 스로 인기를 끌었던 매킨토시처럼 아이포드와
같은 $\mathrm{MP3}$ 플레이어의 성공은 오래 지속되지 못할 것이다.

이러한 측면에서 국내 최대의 이동 통신 서비 스 가입자를 기반으로 하고 있는 멜론은 강력 한 터미널 경쟁력을 확보하고 있다. 실제로 멜 론은 2005년 약 660만명의 MP3 휴대폰 사용자 를 확보(<표 6> 참고)한데 이어 2006년에는 그 수를 약 980만명까지 확대하여 사업 기반을 극 대화하려 한다. 뿐만 아니라 국내 MP3 플레이 어 메이저 제조사 및 글로벌 제조사와의 적극 적 제휴를 통하여 멜론의 서비스 취급이 가능 한 기기의 범위를 확대해 나가고 있다. 이를 통 해 현재 멜론 서비스 가능 기종은 코원 (COWON) 9개, 아이리버(iriver) 8개 등 총 27 개로 확대되었다(<표 7> 참고). 또한, 디지털 오디오 디바이스와 연계한 디지털 카메라+ $\mathrm{MP3}$ 휴대폰, 전자 사전 $+\mathrm{MP} 3$ 휴대폰, $\mathrm{DMB}+$ $\mathrm{MP3}$ 휴대폰, 동영상이 가능한 휴대형 멀티미

<표 6> MP3 휴대폰 사용자 추이 (2005년 기준)

\begin{tabular}{|c|c|c|c|c|c|c|c|c|c|c|c|}
\hline 1월 & 2월 & 3월 & 4월 & 5월 & 6월 & 7월 & 8월 & 9월 & 10월 & 11월 & 12월 \\
\hline 159만 & 163만 & 213만 & 248만 & 288만 & 333만 & 383만 & 433만 & 488만 & 543만 & 603만 & 663만 \\
\hline
\end{tabular}

<표 7> 멜론 서비스 가능 MP3 플레이어 기종

\begin{tabular}{|c|c|c|c|c|c|c|}
\hline 회사 & 레인콤 & 코원 & 삼성 & 아이옵스 & SK C\&C & 디지털 큐브 \\
\hline 모델 & $\begin{array}{c}\text { E10 } \\
\text { 딕플 D20 } \\
\text { T10 } \\
\text { T20 } \\
\text { T30 } \\
\text { H10jr } \\
\text { N11 } \\
\text { U10 }\end{array}$ & $\begin{array}{c}\text { iAUDIO T2 } \\
\text { iAUDIO } 6 \\
\text { iAUDIO U3 } \\
\text { COWON A2 } \\
\text { iAUDIO X5 } \\
\text { iAUDIO F1 } \\
\text { iAUDIO } 5 \\
\text { iAUDIO U2 } \\
\text { iAUDIO G3 }\end{array}$ & YEPP T7F & $\begin{array}{l}\text { 아이옵스 作 } \\
\text { 아이옵스 格 } \\
\text { 아이옵스 秀 } \\
\text { 아이옵스 X5 } \\
\text { 아이옵스 Z3 }\end{array}$ & $\begin{array}{c}\text { C\&C } \\
\text { air/air+ }\end{array}$ & $\begin{array}{c}\text { V43 } \\
\text { V43 POWER } \\
\text { V43 NAVI }\end{array}$ \\
\hline
\end{tabular}


디어 플레이어(PMP: portable multimedia player), 비디오 게임기(PSP:playstation), 그리 고 카 오디오 등 융합형(convergence) 휴대용 디지털 디바이스를 적극 수용하여 최고의 고객 지향성을 확보하였다.

\section{2 고객 지향적 관점에서의 노력}

Luo and Seyedian(2003)의 연구를 살펴보면, 인터넷 비즈니스 상에서 고객 만족도와 충성도 에 영향을 주는 요인은 2 가지로 나타났는데, 하 나는 맥락 마케팅(contextual marketing)이고 다른 하나는 고객 지향성(customer orientation) 이다. 먼저, 맥락 마케팅이란 유비쿼터스의 특 징을 소유한 전자 상거래에 있어 각각의 소비 자에게 맞추어진 개인화된 정보를 원하는 시간 과 장소에 제공하는 행위를 의미한다. 이러한 맥락 마케팅의 도구로는 휴대폰, 휴대용 디지털 기기, 웹 기반 키오스크, 그리고 전자 지갑 등 이 있는데, 예를 들어, 일본 NTT DoCoMo의 I-mode 서비스는 호텔 예약, 식당 위치 파악, 스키 리조트 정보, 그리고 실시간 주식 통계 등 을 무선 기반으로 언제 어디서나 제공한다. 또 한, 고객 지향성이란 실제 필요 욕구가 있는 소 비자들에게 경쟁자와 비교하여 비교 우위가 있 는 가치를 언제 어디서나 지속적으로 제공하는 행위를 의미한다. 이러한 고객 지향성을 실천한 결과는 매우 긍정적인데, 고객 만족, 호의적인 구전, 그리고 반복적인 구매 태도와 행동 등이 나타난다.

인터넷 비즈니스의 형태를 소유하고 있는 멜 론도 앞서 설명한 맥락 마케팅과 고객 지향성 측면에서 다른 경쟁자와 비교하여 차별화된 경
쟁력을 보이고 있다. 먼저, 맥락 마케팅 측면에 서 설명하면, 온라인 음악 시장에 있어 소비자 들은 유료 서비스에 대해 언제 어디서나 이용 할 수 있는 차별화된 이용 편의성을 요구한다. 이것이 해결되지 않은 상황 하에서 소비자들은 지속적으로 불법 복제 시장을 이용할 것이다. 그러나 멜론은 이러한 이용 편의성을 제고 시 켰다. 한편, 고객 지향성 측면에 있어 온라인 음악 시장에 대해 소비자들은 유료 서비스에 대해 강한 거부감을 소유하고 있다. 왜냐하면, 대부분의 소비자들이 무료 서비스에 익숙해 있 기 때문이다. 실제로 곡당 판매액은 500 원이지 만 곡당 지불 의향 금액은 약 150 원으로 나타 났다. 이렇게 높게 설정되어 있는 심리적 가격 의 문제를 해결하지 못한다면, 소비자들의 불법 복제 시장의 이용은 계속될 것이다. 그러나 멜 론은 소비자들의 비용 지불 의향을 제고 시켰 다. 결과적으로 불법 복제 시장에 대응하기 위 해서는 소비자들에게 차별적 가치를 창출하여 제공해 주는 것이 무엇보다 필요한데, 멜론은 소비자들의 이용 편의성을 증대시키고 지불 의 향을 변화시켜 이것을 가능하게 했다. 이에 대 해서는 다음 절에서 자세히 설명하고자 한다. 동시에 멜론이 행한 마케팅 믹스 활동에 대해 서도 설명하고자 한다.

\section{2 .1 이용 편의성 제고의 노력}

이동 통신사 관계자들은 온라인 음악 시장에 서 혁신적 서비스를 이용 가능하게 하는 휴대 폰의 등장이 최근 출시된 애플사의 화상 아이 포드(i-Pod)와 같은 제품들을 침체에 빠뜨릴 수 있을 것이라고 전망하고 있다. 이것은 서로 
<그림 3> 멜론의 유무선 연동 서비스 메카니즘

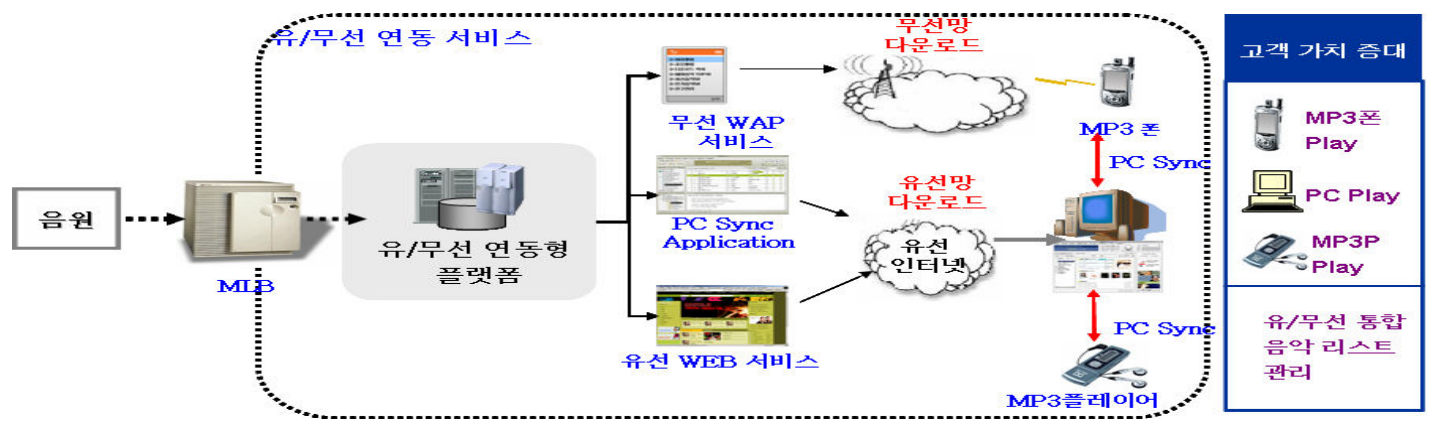

다른 두 산업 영역 간의 대결의 장이 열리는 것을 의미한다. 애플이나 실리콘 밸리의 컴퓨터 관련 전문가들은 컴퓨터가 온라인 음악 시장의 중심점이 될 것이라 전망하고 있고, 핀란드, 한 국, 그리고 미국 등에 있는 주요 이동 통신 관 련 전문가들은 휴대폰이 새로 열릴 온라인 음 악 시장의 핵심 주자가 될 것이라고 전망하고 있다(BusinessWeek 2005).

이러한 상황에서 멜론은 일찍부터 유무선 연동 서비스를 정착시켰다. 즉 기존에 있던 $\mathrm{PC}$ 기반의 서비스는 물론이고 휴대폰을 이용한 서 비스도 가능하게 한 것이다. 이는 글로벌 규모 의 무선 이동 통신사들이 온라인 음악 시장에 서 프론티어가 될 수 있는 가능성을 보여준 것 이다. 실제로 엄청난 양의 곡을 $\mathrm{PC}$, 휴대폰, 그 리고 기타 뮤직 플레이어에 다운 로드 받을 수 있다는 것은 소비자들이 원하는 곡을 언제, 어 디서든 이용 할 수 있는 환경이 조성되었다는 것이다. 이러한 환경은 더 쉽게 소비자들을 끌 어들일 수 있는 요인으로 작용할 수 있다. <그 림 $3>$ 을 통해 살펴보면, 소비자들의 이용 편의 성 제고를 위한 멜론의 노력을 알 수 있다. 그 중심에는 유무선 연동형 플랫폼을 통한 무선 $\mathrm{WAP}$ 과 유선 WEB 서비스가 있다. 이러한 서
비스를 무선망을 통해 직접 $\mathrm{MP} 3$ 휴대폰으로 다운 로드하여 이용하거나 유선망을 통해 PC 로 다운 로드 한 후 이를 다시 $\mathrm{MP3}$ 휴대폰이 나 MP3 플레이어에 다운 로드하여 이용하는 것이다. 이와 같이 유무선 연동 기반의 any time(언제나), any where(어디서나), any device (어느 기기에서나)를 통한 유비쿼터스 음악 감 상을 제공함으로써 유료화가 정착된 무선과 무 료 인식이 팽배한 유선을 통합할 수 있었다. 그 결과 $\mathrm{P} 2 \mathrm{P}$ 불법 복제 시장 대비 차별적 가치가 창출되어 지속적인 매출 성장을 유지할 수 있 었다.

\subsection{2 지불 의향 제고의 노력}

향후 온라인 음악 시장에 있어 가격 체계가 어떠한 방식으로 전개되는 것이 바람직한가에 대한 질문에 대해 매우 상반된 두 가지 견해가 있다. 스프린트(sprint)와 같은 주요 이동 통신 서비스 업체는 무선으로 다운 로드 시 \$2 3 정도, 아이튠스(i-Tunes)로 다운 받을 시에는 $\$ 1$ 정도의 가격을 부과해야 한다고 주장한다. 그 이유는 언제, 어디서든 서비스 받을 수 있는 이용의 편의성과 최초로 서비스를 휴대폰으로 
실현시켰다는 프리미엄적 대가를 인정하기 때 문이다. 그러나 애플사 측은 앞선 이동 통신 서 비스 업체의 주장은 비 현실적이라고 비판하면 서 "만약 당신이 어디선가 곡을 아주 싸게 구 할 수 있는데 그에 대해 $\$ 3$ 에 달하는 돈을 내 라고 한다면 그것은 바보 같은 일이다.”라고 언 급하고 있다(BusinessWeek 2005).

그러나 멜론은 이러한 애플사의 비판과는 다 른 결과를 도출시키고 있다. 무려 $\$ 5$ 가격에 서비스를 제공하고 있음에도 불구하고 지속적 으로 회원을 유치하고 있는 것이다. 현재 휴대 폰이 가지고 있는 매력은 소비자들을 매혹시키 고 있다. 이에 따라 소비자는 음반 매장에 가서 개별적으로 구매하기 보다는 월 정액을 지불하 고 자신이 원하는 모든 음악을 언제, 어디서든 지 들을 수 있는 방법을 선택하는 것이다. 이러 한 결과가 나타날 수 있게 된 것은 온라인 음 악에 대한 소비자의 실질적 욕구를 정확히 파 악하였기 때문이다. 소비자 조사 결과, 온라인 음악 서비스에 대한 유료 사용 비율은 전체 조 사 대상자 중 고작 $1.1 \%$ 에 불과했다. 그리고 곡당 최대 지불 의향 금액은 150 원이었다. 그러 나 한 가지 중요한 사실은 추가 비용 지불 없 이 어떤 기기에서든 사용하려는 비율은 무려 $61.4 \%$ 에 이르렀다. 이 같은 결과를 통해, 멜론 은 소비자의 가격 부담은 줄이고 전체 시장의 크기는 확대하면서 음원 권리자의 수익 또한 극대화할 수 있는 새로운 상품을 개발하였다. 그것이 바로 영구적, 무제한 소유의 개념이 아 닌 일정 기간 음원을 임대하는 렌탈형(monthly rental) 상품이다. 덧붙여 설명하면, $\mathrm{DRM}$ 기술 을 활용하여 $\mathrm{PC}, \mathrm{MP} 3$ 휴대폰, 그리고 $\mathrm{MP} 3$ 플 레이어에서 동일한 서비스를 월 5,000 원의 정액
정보 이용료로 제공하는 철저히 고객 지향적 (예, 소비자 조사 결과 본 상품에 대한 최대 지 불 의향 금액은 월 4,700 원으로 나타남)인 상품 이다. 이를 통해 멜론은 온라인 음악 시장의 유 료화 트랜드를 형성하여 시장 확대의 기반을 구축할 수 있게 되었다.

\subsection{3 강력한 마케팅 능력 발휘}

Horsky and Simon(1983)의 연구 결과를 살 펴보면, 광고가 혁신적인 신제품의 확산 과정에 있어 중요한 역할을 하고 있음을 알 수 있다. 실제로 혁신 제품의 한 형태인 폰 뱅킹을 조사 해 본 결과, 최적의 광고 정책은 제품이 출시되 는 시점에서 많은 광고를 실행하는 것이었다. 그리고 제품 판매가 증가되기 시작하는 시점에 서 광고량의 수준을 감소시켜주는 것이었다.

세계 최초의 유비쿼터스 음악 포털 서비스인 멜론의 가입 계기를 살펴보면, $\mathrm{TV}$ 광고의 효 과가 가장 높은데(전체 $100 \%$ 에서 $20 \%$ ), 이는 도시락 $(6 \%)$, 소리바다(5\%), 벅스 $(4 \%)$ 등의 경쟁사와 비교하여 월등한 수치이다(동서 리서 치 2006). 실제로 멜론의 광고 예산 집행은 경 쟁사 대비 비교 우위에 있는 것이 사실이다. 그 러나 더욱 중요한 것은 광고의 질적 측면이다. Barnett(1968)의 연구를 살펴보면, 신제품의 광 고는 소비자들에게 그 제품의 특별하고 독특한 특징을 제공할 수 있도록 만들어져야 한다. 그 결과, 제품을 명확히 정의할 수 있고 향후 선호 되어지는 것이다. <그림 $4>$ 는 시장에 출시되는 시점에서 소비자에게 노출된 멜론 광고의 한 장면이다. 솔직히 멜론은 소비자들에게 그 브랜 드 컨셉을 인식시키기 어려운 브랜드였다. 그러 


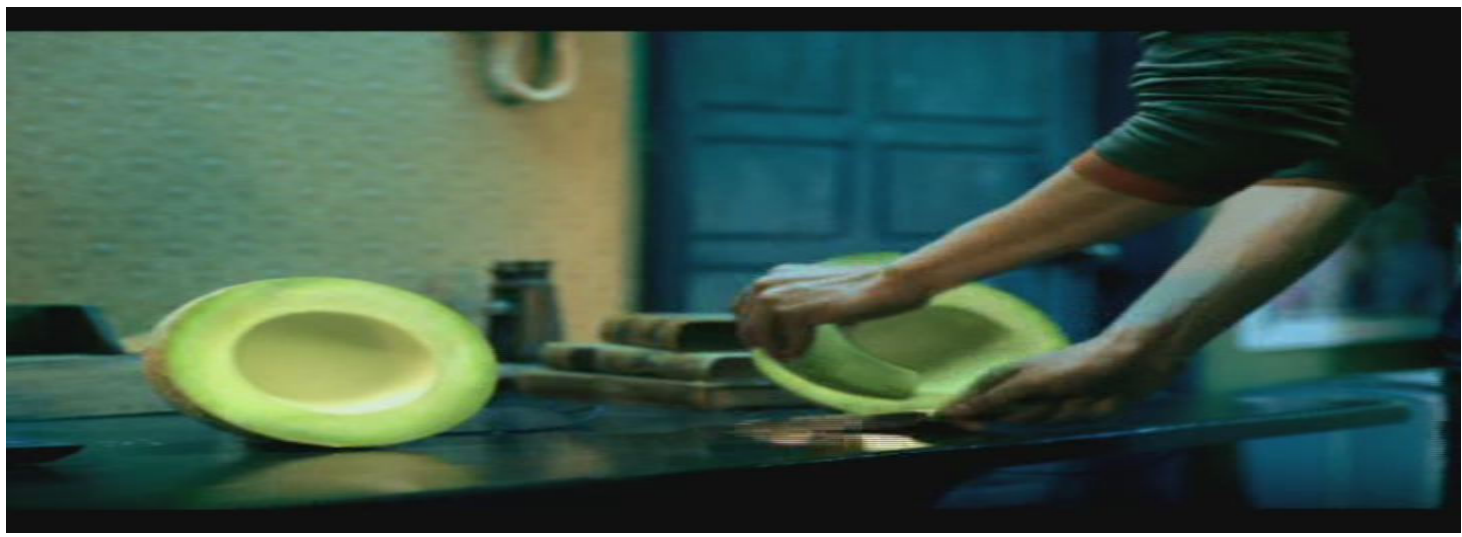

나 광고를 통해 아주 쉽게 소비자들 머릿속에 접근할 수 있었다. 그리고 멜론을 잘라내는 비 주얼로 $\mathrm{MP} 3$ 의 휴대성도 잘 보여 주었다.

브랜드 명(brand name)은 소비자의 마음 속 에 제품을 위치시켜주는데 중요한 역할을 한다. 즉 제품의 명확한 기능이나 다른 제품과 비교 해서 나타나는 혜택의 차이점 등을 빠르게 인 식시켜준다(Ross 1982). 이러한 측면에서 멜론 이라는 브랜드 명은 경쟁사 대비 비교 우위의 마케팅 능력의 실례라고 할 수 있다. 구체적으 로 설명하면, 멜론은 멜로디 온의 줄임말로써 손쉽게 음악 서비스를 떠올리게 한다. 또한, 생 활을 활기차고 상큼하게 바꾸어 주는 혜택이 있을 수 있음을 머리 속에 각인시켜준다.

한편, 멜론은 약 2천만 명의 SK Telecom 휴 대폰 가입자를 활용할 수 있고, 휴대폰 요금 청 구서 또는 자동 결제와 같은 과금의 편의성도 소유하고 있다. 또한, SK Telecom의 대리점, (주)SK의 OK Cashbag으로 연결되어 있는 다 양한 제휴사 및 $\mathrm{CRM}$ 채널 등 강력한 마케팅 채널을 보유하고 있다. 이러한 것 모두 경쟁사 대비 비교 우위의 마케팅 능력이라고 할 수 있다.
3.3 가시적 성과 창출

2004년 11월 출시된 후 2006년 현재까지 2년 이 안된 시점에서, 앞서 언급했던 바와 같이 많 은 노력을 행한 멜론은 혁신 제품이 갖추어야 할 주요 핵심 역량 부분에 있어 가시적 성과를 창출하였다. 먼저, 기술적 부분에 있어서는 국 내 온라인 음악 산업 구조의 기틀을 마련하였 다. 이는 온라인 음악 산업에 진출하려는 많은 업체들에게 거시적 전략 수립 측면에서 많은 도움을 주었다. 구체적으로 설명하면, 소싱 (sourcing), POC, 그리고 터미널(terminal)의 각각의 영역에 대한 소유권 확보를 통해 $\mathrm{S}-\mathrm{P}-\mathrm{T}$ 를 하나로 묶은 서비스를 개발하였다. 즉 $\mathrm{S}-\mathrm{T}-\mathrm{P}$ 에 대한 수직적 통합 모델이 완성된 것 이다. 이는 온라인 음악 산업에 있어 성공을 향 한 선순환 고리를 형성해 주었다. 첫째, 완벽한 소싱 인프라 구축을 통해 경쟁력 있는 $\mathrm{POC}$ 를 구현할 수 있게 되었다. 이는 멜론의 핵심 비즈 니스 영역인 음성(voice) 사업의 경쟁력을 강화 시키는 역할을 하였다. 둘째, 역량이 증대된 $\mathrm{POC}$ 는 보편화된 DRM 서비스와의 연계를 통 
<그림 5> 주간 웹사이트 방문자수 비교 (2005년 11월 2006년 2월)

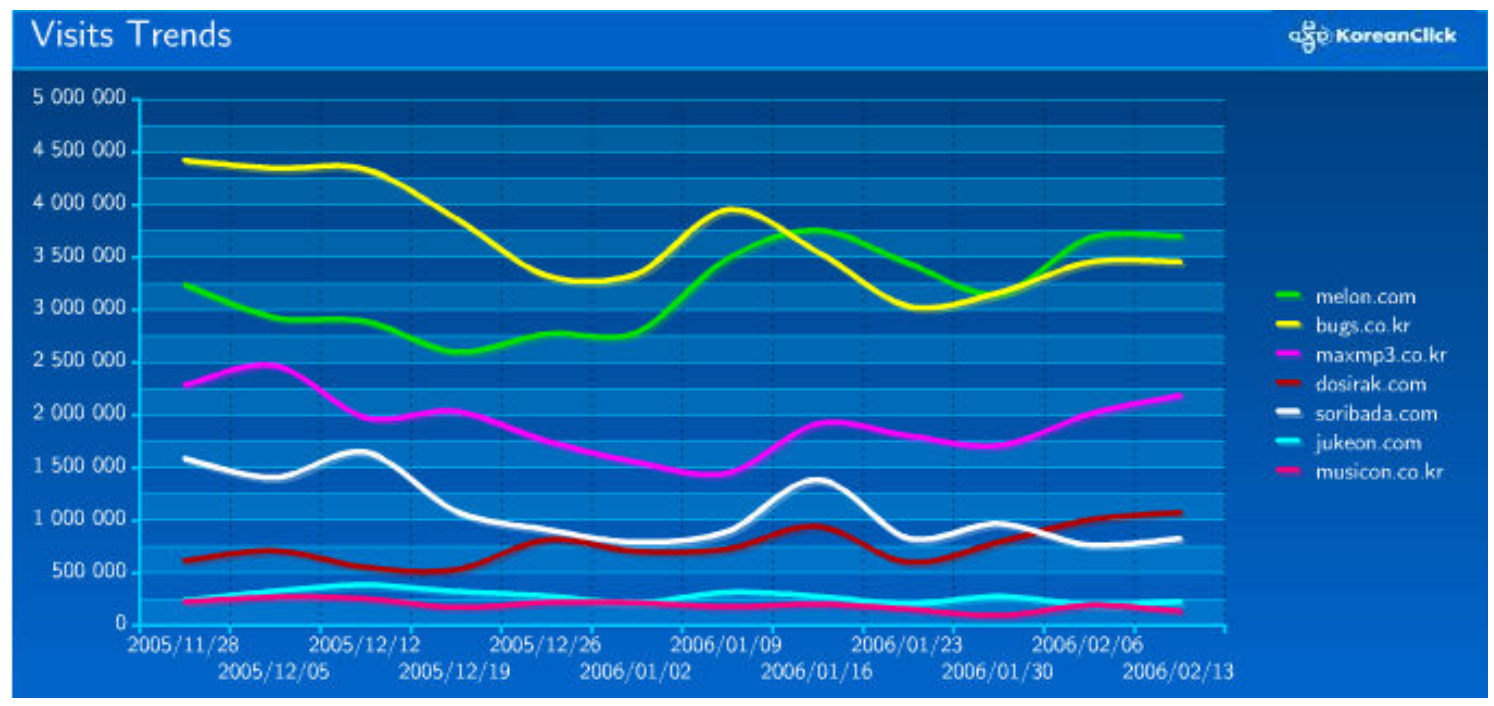

해 터미널의 매력도를 증대시켰다. 셋째, 다양 화된 터미널의 보급 증대로 $\mathrm{POC}$ 의 활성화를 가속화 시켰다. 이는 멜론의 또 하나의 핵심 비 즈니스 영역인 디지털 컨텐츠 유통 센터 구축 의 시금석 역할을 하였다. 마지막으로 역량이 확장된 $\mathrm{POC}$ 는 소비자들의 구매력을 증가시켜 더욱 강력한 소싱 인프라를 구축시킬 수 있었다.

또한, 고객 지향적 부분에 있어서는 국내 온 라인 음악 산업의 수익성 창출을 확인하였다. 이는 온라인 음악 산업에 진출하려는 많은 업 체들에게 자신감을 갖고 마케팅 활동 등 미시 적 전술을 수립하는데 많은 도움을 주었다. 출 시 후 1 년 만에 회원수 420 만명과 유료 정액 회원 58만명을 유치하였고, 2006년 6월 현재 그 숫자는 회원수 580 만명과 유료 정액 회원 78 만 명 (클럽 상품: 프리 클럽 63만명 / 스트리밍 클럽 12만명, 티켓 상품: 3 만명)으로 늘어났다. 참고로 월 매출액은 약 50 억원 수준이다. 이 수 치는 온라인 음악 사이트 유료 가입자 수 1 위
를 나타낸 것인데, 더욱 중요한 것은 월정액 임 대형 서비스인 프리클럽 상품 가입자 수가 월 등히 많다는 것으로 이는 멜론의 차별적 가치 를 보여주고 있는 것이다. <그림 $5>$ 를 살펴보 면, 사이트 방문자수 순위에 있어서도 유료 음 악 사이트 1위임을 알 수 있는데, 2006년 1월 말을 기준으로 벅스를 추월하였다.

\section{$\mathrm{IV}$. 결론 및 전략적 과제}

국내 음악 산업은 2000년 일반 가정에 초고속 인터넷 서비스가 확대되기 전까지 전통 음반 산업 구조가 중심이었다. 반면, 현재는 기존의 전통 음반 산업 시장이 축소되고 온라인 음악 시장이 급격히 성장하고 있다. 이와 함께 무료 로 음악을 다운 받을 수 있는 온라인 사이트 그리고 다운을 받을 수는 없지만 무료로 음악 
을 들을 수 있는 음악 스트리밍 사이트와 같은 불법 시장 또한 급격히 성장하고 있다. 그러나 한 가지 다행스러운 것은 온라인 음악 서비스 이용자들이 점점 유료 온라인 서비스를 이용하 기 시작 한다는 것이다.

이와 같이 짧은 기간 동안 많은 변화가 있었 던 국내 음악 산업에서 SK Telecom의 멜론은 새로운 비즈니스 모델로 성공을 거두었다. 멜론 은 세계 최초의 유비쿼터스 음악 서비스로써 추가 정보 이용료 없는 음악 다운 로드 서비스 뿐만 아니라, 가입한 기간 또는 구입한 티켓 기 간 동안 모든 음악을 무제한으로 스트리밍하여 감상할 수 있다. 이러한 서비스 특징은 경쟁사 유사 서비스 대비 강력한 경쟁력을 소유하게 만들었고, 결과적으로 온라인 음악 서비스 시장 내에서 높은 위상을 갖게 하였다.

그러나 멜론의 성공 배경은 차별적인 서비스 특징에만 국한되어 있지 않다. 멜론은 성과가 높은 혁신 제품이 일반적으로 소유하고 있는 핵심 역량을 갖추려 노력하였다. 특히, 기술 지 향적인 측면과 고객 지향적인 측면에 초점을 맞추어 노력하였다. 동시에 강력한 마케팅 믹스 활동도 병행하였다. 먼저, 기술 지향적 관점에 서는 첫째, 유료 온라인 음악 시장에서 최강의 음원을 보유하기 위해 소싱 영역에서 경쟁력을 확보하려 하였다. 둘째, 확보한 음원을 안정적 으로 공급하기 위해 $\mathrm{POC}$ 영역에서 경쟁력을 확보하려 하였다. 마지막으로 안정적으로 공급 된 음원을 소비자들이 편리하게 들을 수 있게 터미널 영역에서 경쟁력을 확보하려 하였다. 또 한, 고객 지향적 관점에서는 맥락 마케팅과 고 객 지향성 측면에서 다른 경쟁자와 비교하여 차별화된 경쟁력을 확보하려 하였다. 첫째, 맥
락 마케팅 측면에서는 소비자들이 언제 어디서 나 유료 온라인 음악 서비스를 이용할 수 있도 록 이용 편의성을 제고하였다. 둘째, 고객 지향 성 측면에서는 유료 서비스에 대해 강한 거부 감을 소유하고 있던 소비자들의 지불 의향을 제고하였다. 한편, 마케팅 믹스 활동에서는 멜 론의 특별하고 독특한 특징을 제공할 수 있도 록 만든 광고, 소비자의 마음 속에 제품을 위치 시켜주는데 중요한 역할을 한 브랜드 명, SK Telecom 휴대폰 가입자를 활용한 과금의 편의 성, 그리고 SK Telecom의 대리점과 같은 강력 한 마케팅 채널 전략을 실행하였다.

이러한 노력으로 멜론은 혁신 제품이 갖추어 야 할 주요 핵심 역량 부분에 있어 가시적 성 과를 창출하였다. 먼저, 기술적 부분에 있어 $\mathrm{S}$ (소싱 $)-\mathrm{P}(\mathrm{poc})-\mathrm{T}$ (터미널) 수직 모델을 수립하 여 국내 온라인 음악 산업 구조의 기틀을 마련 하였다. 이는 온라인 음악 산업에 진출하려는 많은 업체들에게 거시적 전략 수립 측면에서 많은 도움을 주었다. 또한, 고객 지향적 부분에 있어서는 온라인 음악 사이트 유료 가입자 수 1 위와 온라인 음악 사이트 방문자 수 1 위를 달 성하여 국내 온라인 음악 산업의 수익성 창출 을 확인하였다. 이는 온라인 음악 산업에 진출 하려는 많은 업체들에게 자신감을 갖고 마케팅 활동 등 미시적 전술을 수립하는데 많은 도움 을 주었다.

그러나 멜론이 지금보다 발전된 성과를 도출 시키기 위해서는 다음과 같은 전략적 과제를 해결해야 한다. 첫째, SK Telecom 자체의 $\mathrm{DRM}$ 을 사용함으로써 기기의 호환성에 문제가 있다. 실제로 멜론 서비스는 현재 일부 $\mathrm{MP} 3$ 플레이어 및 타사 MP3 휴대폰에서는 이용이 
불가능하다. 둘째, 음악 유통 사업자와의 수익 분배에 있어 구조상의 문제가 있다. 따라서 정 보 이용료를 기준으로 할 경우 손익 분기점에 도달하는 기간을 예측하는데 어려움이 있다. 셋 째, SK Telecom은 이동 통신 서비스 시장에서 지배적 사업자로써 정보 통신부, 문화 관광부, 그리고 공정 위원회 등 정부 측 규제가 예상된 다. 또한, 대기업의 음악 산업 진출로 인해 $\mathrm{NGO}$, 경쟁 기업, 음반 회사 등 여러 이익 단체 들의 견제가 예상된다. 넷째, 서비스 오픈 초기 에 조직 구성원들이 가지고 있었던 벤쳐 정신 이 결여되어 발 빠른 서비스 개발이 부족한 실 정이다. 마지막으로 온라인 음악 시장 안에 있 는 소비자들의 행동 트랜드에 규칙성이 없다. 제품 수명 주기(PLC) 상 성장기에 있는 시점 에서 소비자들이 지속적으로 사이트를 방문하 고 컨텐츠를 이용해 주어야 하지만 실제로는 그렇지 못한 실정이다. 또한, 성숙기로 발전하 기 위해서는 온라인 음악 시장 특성 상 긍정적 구전 효과가 중요하지만 이용자 수가 정체되고 있어 활성화되고 있지 못한 실정이다. 이상 다 섯 가지의 문제에 대해서는 지속적인 고민이 필요하고 신속한 대응 방안의 수립이 요청된다. <논문 접수일: 2006. 09. 30> <게재 확정일: 2006. 09. 30>

\section{참고문헌}

고정민, 민동원(2003), "국내 음반산업의 주요 이슈와 대응방안," 삼성경제연구소, 2003.

2. 11.

김남훈(2005), “온라인 음악시장," 하나금융연

구소, 2005. 3. 2.

동서리서치(2006), “멜론' 경쟁력 강화를 위한 소비자 조사 보고서," 동서리서치, 2005. 4. 14.

멜론 홈페이지, http://www.melon.com Barnett, Norman L.(1968), "Developing Effective Advertising for New Products," Journal of Advertising Research, 8(4), 13-18.

BusinessWeek(2005), "iPod Killers?," April. Gatignon, Hubert and Jean-Marc Xuereb (1997), "Strategic Orientation of the Firm and New Product Performance," Journal of Marketing Research, 34(February), 77-90.

Horsky, Dan and Leonard S. Simon(1983), "Advertising and the Diffusion of New Products," Marketing Science, 2(1), 1-17. Luo, Xueming and Mojtaba Seyedian(2003), "Contextual Marketing and CustomerOrientation Strategy for E-Commerce: An Empirical Analysis," International Journal of Electronic Commerce, 8(2), 95-118. Ross, Ivan(1982), "The Effect of Brand Names," Advances in Consumer Research, 9(1), 478-480. 


\title{
Successful Business Model on Music Industry: SK Telecom MelOn
}

\author{
Pil Hwa Yoo* \\ Sukekyu Lee** \\ Kyoungsik Kim***
}

\begin{abstract}
On November 16th 2004, SK Telecom Co., Ltd. launched 'MelOn' , an ubiquitous music service, into the first time in the world. It, new business model in Korea, was a great success in domestic music industry. Its key success factors are not only differential features of service but also the superiority of technical know-how, customer-oriented spirit, and marketing mix activities compared to many competitors. The case shows how MelOn developed and then introduces what on-line music service is identifying the key success factors and presenting visible outcomes. Furthermore discussing its business implications and future challenges.
\end{abstract}

Key words: MelOn, music industry, successful business model, ubiquitous music service

* Professor, Graduate School of Business Sungkyunkwan University

** Associate Professor, School of Business Sungkyunkwan University

*** Business Analyst(Ph. D.), Research Institute of Management, Sungkyunkwan University 